\title{
US biomedical research faces financial stringency
}

\section{After five years of sustained growth, US biomedical research is once again about to face a period of austerity. David Dickson reports.}

Since 1975, the growth of support for biomedical research in the US has outstripped virtually all other areas of the science budget. But fiscal stringency and changing social priorities are bringing this to an end and biomedical scientists will soon face some hard decisions as they adjust to the budgetary austerity destined to characterise the early 1980 s.

The Administration has already adopted "stable funding"' as the cornerstone to its strategy and in its budget request for the fiscal year 1981, due to be presented to Congress by President Carter next month, "stabilisation" is expected to be interpreted as the need to maintain the number of new grants for investigator-initiated research projects at its current level of about five thousand per year.

By doing this, the Administration hopes to provide some protection for the "science base" of its health research programme, steering public discussion of resource allocation to areas more directly related to specific health problems.

Research planners are worried, however, that unless this form of stablisation is accompanied by an adequate growth in the overall budget, it could lead to serious difficulties in other areas of the science base - such as the intramural research of the National Institutes of Health, or its support for research centres.

Last week Dr Donald Fredrickson, director of NIH, held a meeting of his advisory committee in Bethesda to discuss the implications of a stabilisation strategy based on a low rate of growth. Introducing the meeting, he made it clear that budgetary stringency increased the need for the institutes to be "in the best posture to react to congressional action".

$\mathrm{He}$ listed three external sources of pressure to which NIH was having to respond. The first is a process initiated last year by Mr Joseph Califano, then Secretary for Health, Education and Welfare, aimed at placing health research planning including support for fundamental research related to health applications on a five-year basis.

The second source of pressure is a bill introduced into Congress earlier this year by Senator Edward Kennedy proposing, among other things, a presidential commission for health sciences, which would be responsible for recommending budgets and research priorities over a fiveyear period. The third is the imminent announcement of the President's 1981 budget request.

Of the three, it is the last which is

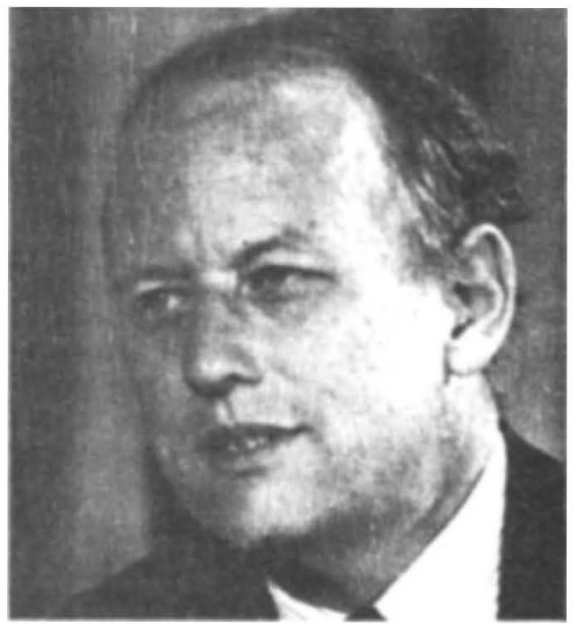

Fredrickson: preparing NIH for congressional action

currently receiving the closest attention within the Administration. In the five years 1974 to 1979, the research budget of DHEW, over $90 \%$ of which passes through $\mathrm{NIH}$, increased from $\$ 2$ to $\$ 3$ billion, an average increase of $10 \%$ a year, considerably higher than the science budgets of most other federal agencies.

But the rate of growth has now slackened. In his 1980 budget request, President Carter initially proposed no increase for biomedical research. As expected, this was subsequently changed by Congress, which voted an $8 \%$.

The precise budget figures for 1981 are still under discussion. However there are indications that, as last year, the President may ask for virtually no increase in funding - and that Congress will be even more reluctant to add to the request.

As for funding priorities, Dr Gilbert Omenn, Associate Director of the Office of Science and Technology Policy, told the members of the advisory committee that the Administration was proposing to emphasise the desirability of keeping up the number of competitive research grants, even if this meant putting additional pressure on the rest of the system.

"We are intending to protect the individual research awards against the type of encroachment that took place in the early 1970s" Dr Omenn said. Stabilisation of research funding was not an ideal solution, but it was a pragmatic approach to the present climate.

Earlier in the day, however, several speakers described the potential consequences of stabilising competitive grants without at the same time ensuring an adequate level of overall support. $\mathrm{Dr}$ William Raub, for example, Associate Director of NIH for Intramural Research, said that if the number of competing grants were kept constant but there was no net increase in the budget, funding for other activities supported by NIH could drop $50 \%$ over a five-year period.

Details of how a budget squeeze could affect the intramural programmes of NIH were described by Dr Robert Goldberger, recently appointed Deputy Director for Science. In 1979, mandatory costs such as salaries absorbed $72 \%$ of the intramural budget. Even with a $7 \%$ budget increase in 1981 , NIH would theoretically have to reduce its workforce by about $14 \%$ if it chose this way to maintain the same balance between mandatory and other costs, he said.

Also affected by a budget squeeze would be the National Library of Medicine. Dr Martin Cumming, Director of the Library, told the committee that the inflation rate for libraries was running at about twice the national inflation rate, and that current funding levels made it very difficult to maintain a fully comprehensive service.

Having identified the possible hazards ahead, Dr Fredrickson reminded the members of the committee that, however antagonistic scientists might be to attempts to forecast future research needs and priorities, some attempt at rationalising the total effort was needed to gain congressional support.

Congress had recently wearied of trying to provide adequate support for research into each disease - what was now needed was to convince legislators to guarantee support for a research floor. "The word 'floor' is political, because we all know that we can do more quality science than we can support. The word 'floor' is trying to convince people that there should be a minimum," Dr Fredrickson said. $\mathrm{Mr}$ Califano has already committed the Administration to seeking ways of ensuring stable and predictable funding for biomedical research, arguing in particular that a five-year forward plan would help protect research funding from short-term political considerations.

Mr Califano's proposals received a relatively rough ride when they were debated by the scientific community at a conference held at NIH in October last year. Many speakers insisted that the prime need was for more money, not a different type of management.

More enthusiastic support, however, subsequently came from the Institute of Medicine. A panel of the institute came out in favour of long-range planning, arguing that it offered the "best assurance that there will be optimal allocation of resources for health research''.

The IoM report, whose main conclusions were outlined to $\mathrm{Dr}$ Fredrickson's advisory committee by institute president Dr David Hamburg, endorsed the idea of a five-year plan for health services research. And to help preserve long-term stability of funding, it suggested setting up a permanent mechanism for regularly reviewing and updating the plan, a recommendation subsequently quoted by Senator Kennedy 
in support of his own proposal for a presidential commission.

At the NIH there is considerable concern about such proposals. Many fear the implication that it might remove from the institutes responsibility for deciding how basic research funds should be allocated. In terms strongly reminiscent of the debate in Britain that followed the proposals made by Lord Rothschild for reorganising medical research in the early 1970 s, they argue that planning is only effective when it is done by those with responsibility for carrying out the resultant decisions.

Dr Fredrickson's reluctance to see the $\mathrm{NIH}$ lose its grip on setting scientific priorities was endorsed by several advisory committee members. "In today's world it is often desirable to have a document available that you can refer to as your plan. But the greatest value of such a document is in its preparation - often the plan itself is best forgotten once it has been conceived" said Mr Benno C Schmidt, previously chairman of the President's cancer commission.

Other speakers recommended that if there were to be outside advice provided to government policy-makers, it should focus on management issues, rather than on the disaggregation of scientific priorities. "In five years as a member of the Defense
Science Board, I can remember only having discussed a scientific issue once. In the vast majority of cases we were involved with ways of helping the Department of Defense manage its resources better," said Dr Ivan Bennett, Provost and Dean of the New York University Medical Center.

Yet the issue of public participation is unlikely to be resolved that easily. One of the most controversial sections of the bill proposed by Senator Kennedy, due to be voted on by the Human Resources Committee in the next few weeks, is public participation in the peer review process, an idea anathema to most working scientists.

Mr Califano has previously expresed DHEW's strong opposition to the bill. Yet among the principles on which he has said health research should be established, it is stated that "to assure that HEW health research is responsive to public concerns, the public must participate in the setting of research policies and priorities".

So far, public participation has been interpreted largely as public comment, rather than significant involvement in decision-making.

"The process of public participation has been highly successful numerically, but not so effective in terms of give and take," said Dr Omenn. Despite the amount of material, there had not been much cross- cutting between people with a stake in the current system, and those with other ideas.

There will be a further opportunity for public debate soon when DHEW publishes a set of possible research initiatives for 1980 to 1984 . These have been prepared by a steering committee under Dr Fredrickson as an attempt to convert Mr Califano's "principles" into budget language. And they are expected to include "trans-NIH" programmes in subjects such as smoking and nutrition, as well as the suggested stabilisation of research project grants currently being pushed by OSTP.

The progress of next year's budget request through Congress will indicate how well these proposals, and the philosophy behind them, fare in the world of realpolitik. Dr Omenn reminded committee members that there might soon be a change in command in the Senate apropriations subcommittee responsible for medical research and that among potential candidates was Mr William Proxmire, no great friend of the research community.

"The numbers that we are proposing can be argued about", he said. But a stabilising strategy was important because it was "the type of process that those people who may dominate the appropriations committees for the next few years will be able to agree on".

\section{Research on foot and mouth virus approved}

In the first major decision on potentially hazardous experiments requiring special permission under federal safety guidelines, the recombinant DNA advisory committee of the US National Institutes of Health has given its approval in principle for experiments to be carried out on foot and mouth virus. Research workers hope that the research will eventually lead to the production of a new vaccine against the disease, a major threat to cattle in many parts of the world, and provide important information about antigenicity mechanisms.

The advisory committee last week recommended to the Director of NIH, Dr Donald Fredrickson, that he approve an application for such experiments that have been made jointly by scientists at the Plum Island Animal Disease Centre of the US Department of Agriculture - the only place in the US currently allowed to cultivate and study foot and mouth disease (FMD) virus - and the San Francisco firm, Genentech.

However before giving the experiments detailed approval, the committee has appointed a subcommittee to study the infectivity of the virus's genome and it is insisting that when genetic material from the virus is studied or transported, it should be in lengths short enough to ensure that there is virtually no danger of infection.

Under the NIH guidelines for recombinant DNA experiments, foot and mouth disease virus belongs to the set of pathogenic organisms on which experiments are prohibited without the specific approval of the Director of NIH.

The research proposal is aimed at identifying that part of the genetic material which codes for a protein attached to the virus surface which, if produced and administered in sufficient quantities,

\section{Carter sacks nuclear regulation chief}

Following consideration of the report of the Kemeny commission on last March's accident at the Three Mile Island nuclear plant, President Carter announced last week that he was replacing Mr Joseph Hendrie as chairman of the Nuclear Regulatory Commission.

However the President said that the accident had not changed his views about the need for nuclear power. "We cannot shut the door on nuclear energy", he said. Recent events in Iran had shown the "clear, stark dangers" of excessive dependence on imported oil.

President Carter said that he agreed fully with the "spirit and intent" of the Kemeny commission's recommendations. However, he urged that the NRC should complete its current internal review during which no new licenses or construction permits are being issued - "as quickly as possible," and in any event "no later than six months from today". would make an effective vaccine. Current vaccines are made from the whole virus, and the production techniques necessary to produce the 800 million doses of the vaccine used annually throughout the world are thought to be partly responsible for some of the outbreaks of the disease.

Under the research proposal submitted to NIH, research workers on Plum Island will produce double-stranded DNA from the FMD virions. Plasmids containing subgenomic fragments of the DNA will be prepared using the disabled $E$. coli $\mathrm{K} 12$ strain of bacteria and, after suitable testing against infectivity, will be transferred to Genentech in San Francisco.

Here the fragments will be characterised to identify that part of the genome corresponding to the desired protein. Once this has been achieved the protein can be expressed in $E$. coli, and it will then be tested for antigenic and immunogenic potency on animals at Plum Island.

At its meeting last week, the advisory committee agreed that it was important that the experiments should be carried out for both economic and scientific reasons. Its main concern was to ensure that the genome was fragmented so that infection was virtually guaranteed to be impossible.

One way to do this, according to Dr Howard Bachrach, the principal investigator on Plum Island, was to divide the genome into two segments, the longer one of which research workers at Pirbright in England had shown to be non-infective. 